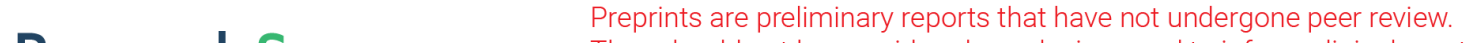 They should not be considered conclusive, used to inform clinical practice, or referenced by the media as validated information. \\ Essential Features for Antioxidant Capacity of Ascorbic Acid (Vitamin C)
}

\author{
Kelton L. B. Santos
}

Universidade Federal do Amapá

Vitor A. N. Bragança

Universidade Federal do Pará

Larysse V. Pacheco

Universidade Federal do Pará

Sirlene S. B. Ota

Universidade Federal do Pará

Christiane P. O. Aguiar

Universidade Federal do Pará

Rosivaldo S. Borges ( $\square$ rosborg@ufpa.br)

Universidade Federal do Pará https://orcid.org/0000-0003-2062-6273

\section{Research Article}

Keywords: Ascorbic acid, Antioxidant mechanism, Pharmacophore, DFT, Redox capacity.

Posted Date: July 23rd, 2021

DOl: https://doi.org/10.21203/rs.3.rs-723156/v1

License: (c) (i) This work is licensed under a Creative Commons Attribution 4.0 International License.

Read Full License

Version of Record: A version of this preprint was published at Journal of Molecular Modeling on December 3rd, 2021. See the published version at https://doi.org/10.1007/s00894-021-04994-9. 


\title{
Essential features for antioxidant capacity of ascorbic acid (vitamin C)
}

\author{
Kelton L. B. Santos ${ }^{1,2} \bullet$ Vitor A. N. Bragança ${ }^{2} \bullet$ Larysse V. Pacheco $^{2} \bullet$ Sirlene S. B. Ota $^{2} \bullet$ \\ Christiane P. O. Aguiar ${ }^{2} \cdot$ Rosivaldo S. Borges*,2 $^{2}$ \\ ${ }^{1}$ Departamento de Ciências Exatas e Tecnológicas, Universidade Federal do Amapá, 68903-419, \\ Macapá, AP, Brazil. \\ ${ }^{2}$ Núcleo de Estudos e Seleção de Moléculas Bioativas, Instituto de Ciências da Saúde, \\ Universidade Federal do Pará, 66075-110, Belém, PA, Brazil.
}

\begin{abstract}
Vitamin $\mathrm{C}$ or ascorbic acid is an indispensable micronutrient for human health found principally on citrus species such as lemon and orange fruits, and vegetables. It was involved in the production of proteins such as collagen. Its biochemical mechanism is related to its antioxidant capacity, however its function at the cellular level is still unclear. Several theoretical studies about antioxidant and redox mechanisms for ascorbic acid were suggested, however no derivative was proposed. Thereby, an electronic study of antioxidant capacity for ascorbic acid derivatives was performed using theoretical chemistry at the DFT/ B3LYP/6-311++(2d,2p) level of theory. Simplified derivatives show that enol hydroxyls are more important than any other functional group. The vicinal enolic hydroxyl on $\beta$-position are more important for antioxidant capacity of ascorbic than hydroxyl on $\alpha$-position. According to our molecular modifications, the keto-alkene compound showed the best values when compared to ascorbic acid in some molecular characteristics. New promising structural derivatives related to ascorbic acid can be developed in the future.
\end{abstract}

Keywords Ascorbic acid • Antioxidant mechanism • Pharmacophore • DFT • Redox capacity.

Contact email: rosborg@ufpa.br (Rosivaldo S. Borges)

\section{ORCID}

Kelton L. B. Santos: https://orcid.org/0000-0002-5704-5707

Vitor A. N. Bragança: https://orcid.org/0000-0003-2772-5717

Larysse V. Pacheco: https://orcid.org/

Sirlene S. B. Ota: https://orcid.org/0000-0003-3123-1058

Christiane P. O. Aguiar: https://orcid.org/0000-0002-5015-0678

Rosivaldo S. Borges: https://orcid.org/0000-0003-2062-6273 


\section{Introduction}

Ascorbic acid (AA) or vitamin $\mathrm{C}$ is an essential micronutrient for human health, acquired mainly through citrus fruits, such as lemon and orange, and vegetables, with antioxidant activity and involved in the production of proteins such as collagen, although its function at the cellular level is still unclear [1, 2]. Its deficiency can cause hemorrhagic condition (scurvy) of the skin and gums with an attack on collagen in the connecting tissues [3, 4].

Chemically, the structure (Figure 1) is composed of a lactone ring (in red) and two enolic hydroxyls (in green), in addition to a primary and a secondary alcohol group (in blue). The two intermolecular hydrogen bonds contribute substantially to the stability and chemical qualities of the molecule [5]. The enolic form of $\alpha$-ketolactone, known as (R)-3,4-dihydroxy-5-((S)-1,2dihydroxyethyl)-furan-2(5H)-one, is easily oxidized in the form of diketo (dehydroascorbic acid) and converted to oxalic acid, diketogulonic acid or threonic acid [5]. AA is an electron donor and therefore a reducing agent, resulting from all its known physiological and biochemical actions. It has an ability to donate a hydrogen atom and form a relatively stable ascorbyl free radical, thanks to its low electron potential and resonance stability. Yet, it donates two electrons from a double bond between the second and third carbons of the 6-carbon molecule. In addition, it plays a role in purifying reactive oxygen species (ROSs) and nitrogen, superoxide, ozone, among others, maintaining the intracellular redox balance and minimizing the oxidative damage caused by these free radicals [1, 3, 5-9].
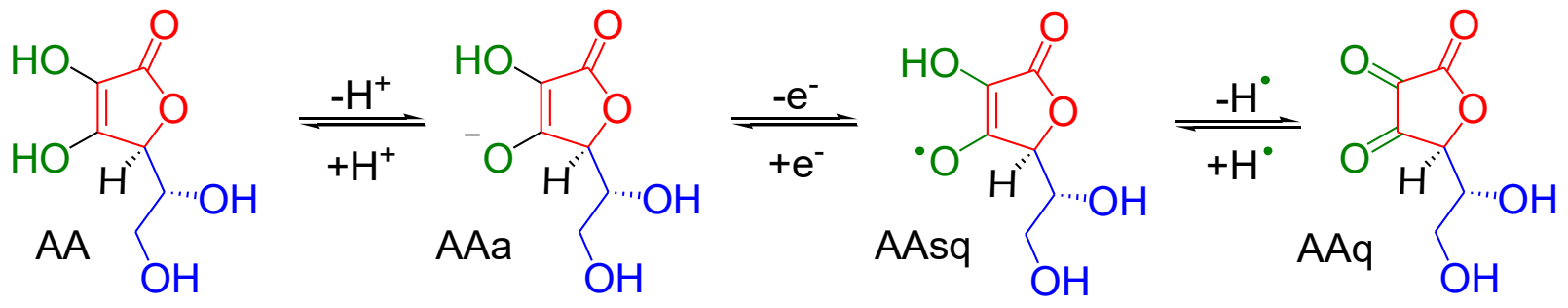

Fig. 1 Redox cycle of ascorbic acid (AA) in anion (a), semiquinone (sq) and ascorbate quinone (q).

AA has been widely used in the treatment and prevention of cancer, although its clinical results are still inconclusive. At low concentrations, it has an antioxidant role, preventing oxidation, which induces apoptosis [1, 10]. Physiological concentrations of ascorbate demonstrated inhibition of LDL oxidation and a synergistic action with vitamin $\mathrm{E}$ preventing lipid oxidation of cell membranes [1, 11, 12].

Based on their activity, antioxidants can be categorized as enzymatic and non-enzymatic. Enzymatic antioxidants work by breaking down and removing free radicals. To understand the mechanism of action of antioxidants, it is necessary to understand the generation of free radicals and their damaging reactions [13]. 
AA changes to the ascorbate radical by donating an electron to the lipid radical to terminate the lipid peroxidation chain reaction. The pairs of ascorbate radicals react quickly to produce an ascorbate molecule and a dehydroascorbate molecule (without antioxidant activity), the latter being converted back to ascorbate by the addition of two electrons, probably due to the action of oxidoreductase [13, 14].

Despite the instability of ascorbic acid in solution has been known for almost a century, the kinetics and mechanism of degradation, along with the influence of experimental conditions are still debated and controversial. Product studies indicate that, under aerobic conditions in an aqueous environment, the stages of degradation of the formal oxidation of two electrons by molecular oxygen produces dehydroascorbic acid, which is hydrolyzed to diketogluconic acid and, subsequently transformed into a variety of products [14-16].

\section{Methodology}

All the calculations were performed with the Gaussian 09 molecular package [17]. The PM3 geometries [18] were optimized with the DFT/B3LYP hybrid density functional [19-21] by using the 6-311++G(2d,2p) basis set [22]. Based on lowest energy structures of neutrals (Mol or AA), cation free radicals $\left(\mathrm{Mol}^{\cdot+}\right.$ or $\left.\mathrm{AA}^{\cdot+}\right)$, semiquinones $\left(\mathrm{Mol}^{\bullet}\right.$ or $\left.\mathrm{AA}^{\bullet}\right)$, and anion free radicals $\left(\mathrm{Mol}^{\circ}\right)$, four antioxidant mechanisms were explored (Figure 2). Reactive species such as cation free radical $\left(\mathrm{RS}^{\bullet+}\right)$ or semiquinone $\left(\mathrm{RS}^{\bullet}\right)$ are disassembled by means of electron or hydrogen scavenging. Usually, the single electron transfer (SET) and the hydrogen atom transfer (HAT) are the main antioxidant mechanisms, however there are many other [23]. The ionization potential (IP) was calculated as the energy difference between a neutral molecule (Mol) and its respective cation free radical (1). The SET was calculated, as showed in equation 2, as a difference between ascorbic acid neutral and cation free radical (AA and $\mathrm{AA}^{\bullet+}$ ) minus all other derivatives $\left(\mathrm{Mol}\right.$ and $\mathrm{Mol}^{\circ+}$ ) [24-30]. The sequential proton lost electron transfer (SPLET) values were calculated as the difference between semiquinone $\left(\mathrm{Mol}^{\circ}\right)$ and its respective anionic form $\left(\mathrm{Mol}^{-}\right)$(3). The bond dissociation energy of enol moiety $\left(\mathrm{BDE}_{\mathrm{OH}}\right)$ was calculated as the energy difference between a neutral molecule (Mol) and its respective semiquinone plus hydrogen (4). The HAT was calculated, as showed in equation 5, as a difference between ascorbic acid (AA) minus all other derivatives (Mol). The single electron acceptance (SEA) values were calculated as the difference between anion free radical ( $\mathrm{Mol}^{\circ}$ ) and its respective quinone form (MolQ) (6).

$$
\begin{aligned}
& S E T=E M o l^{+}-E M o l \\
& S E T=\left(E A A^{\cdot+}+E M o l\right)-\left(E A A+E M o l^{++}\right) \\
& S P L E T=E M o l^{-}-E M o l \\
& B D E_{O H}=\left(E M o l+E H^{\bullet}\right)-(E M o l) \\
& H A T=\left(E A A^{\bullet+}+E M o l\right)-\left(E A A+E M o l^{\circ+}\right) \\
& S E A=E M o l^{\bullet-}-E M o l
\end{aligned}
$$


a) Ionization Potential (IP)

Single Electron Transfer (SET)
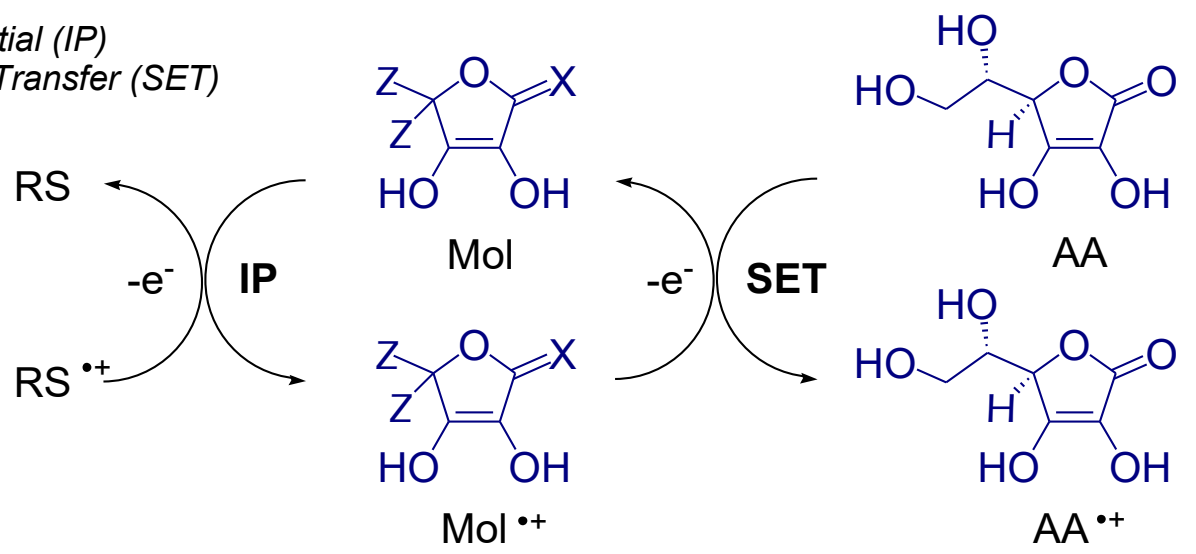

b) Sequential proton loss electron transfer (SPLET)

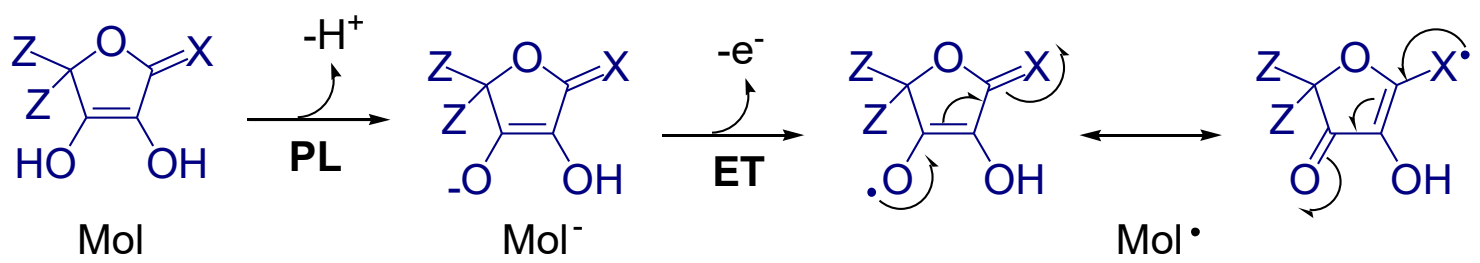

c) Bond Dissociation Energy of Enol (BDE $\left.\mathrm{OH}_{\mathrm{H}}\right)$

Hydrogen Atom Transfer (HAT)
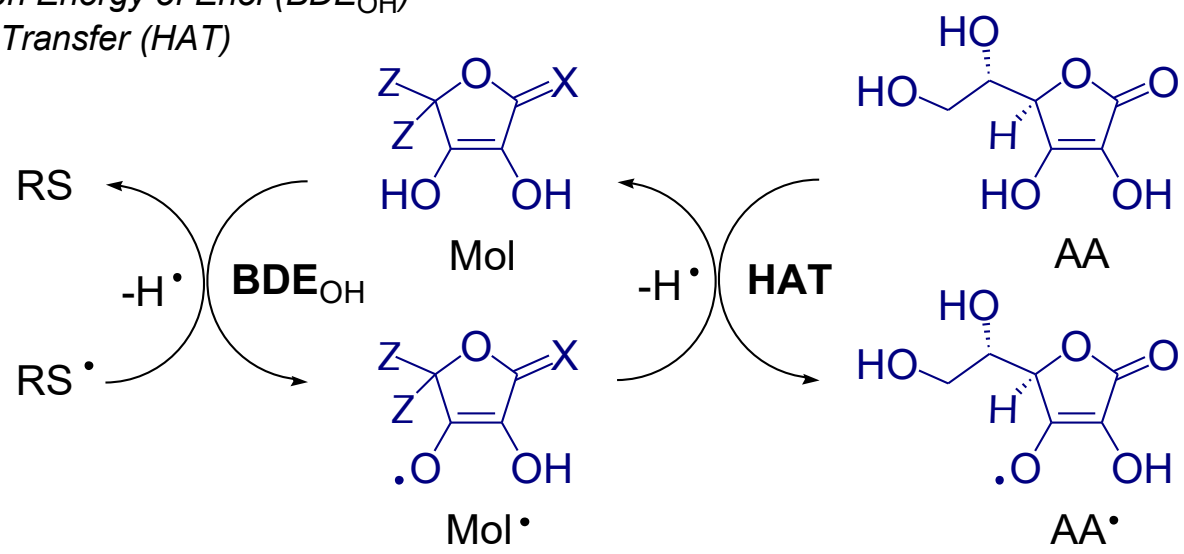

d) Bond Dissociation Energy of Enol (BDE $\left.\mathrm{OH}_{\mathrm{H}}\right)$ and Single Electron Acceptance (SEA)

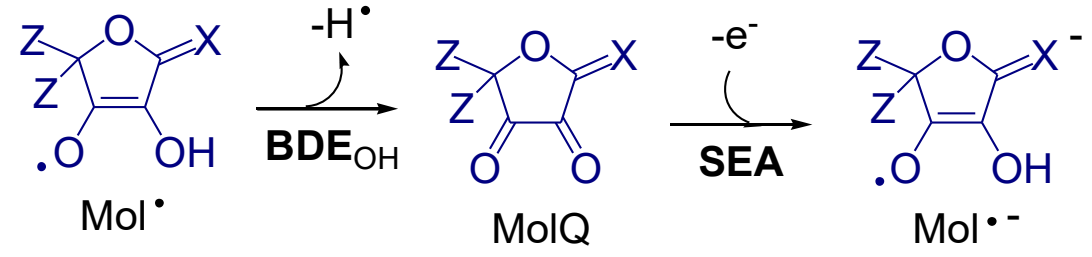

Fig. 2 Proposed antioxidant mechanism on redox process of ascorbic acid and simplified derivatives.

\section{Results and discussion}


In this study, the molecular modifications of ascorbic acid (1) are compared with their simplified derivatives by using molecular simplification on furanone system (2-5) and compared to furan ring derivatives (6-9). These compounds are showed in Fig. 3.
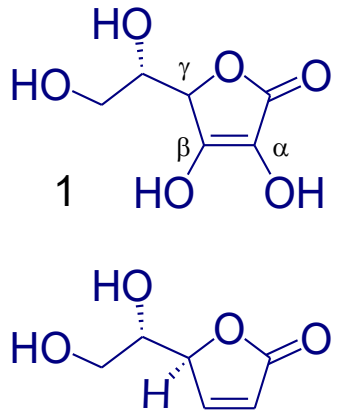

4

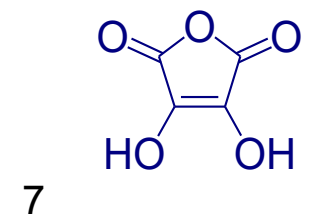<smiles>O=C1C=C(O)[C@H]([C@H](O)CO)O1</smiles>
5<smiles>O=C1OCC(O)=C1O</smiles><smiles>O=C1CCC(O)=C1O</smiles><smiles>O=C1OC([C@@H](O)CO)C=C1O</smiles>

6<smiles>OC1=C(O)COC1</smiles><smiles>O=C1C=CC(O)=C1O</smiles>

Fig. 3 Chemical structures of ascorbic acid (1) and its simplified derivatives (2-9).

According to theoretical results described in Table 1, the ionization potential (IP) and single electron transfer (SET) values have indicated a lesser variation between ascorbic acid (1) and derivative 5 of 193.51 and $202.15 \mathrm{kcal} / \mathrm{mol}$, when compared to compounds ( 2 and 3 ) without a hydroxyl (211.49 and $206.14 \mathrm{kcal} / \mathrm{mol})$ or non-hydroxylated $(210.17 \mathrm{kcal} / \mathrm{mol})$ as observed in molecule 4, linked to the lactone ring. The same trend was observed for the transfer of a hydrogen, with enolic bond dissociation energy $\left(\mathrm{BDE}_{\mathrm{OH}}\right)$ values of 80.97 and $86.24 \mathrm{kcal} / \mathrm{mol}$ for ascorbic acid (1) and 82.75 and $87.20 \mathrm{kcal} / \mathrm{mol}$ for derivative $\mathbf{5}$, considering the $\beta$ and $\alpha$ position of the enolic group. In addition, according to the $\mathrm{BDE}_{\mathrm{OH}}$ values, $\mathbf{2}$ and $\mathbf{3}$ compounds showed the importance of the diol system due to the increase of $\mathrm{BDE}_{\mathrm{OH}}$ values to 91.70 and $99.99 \mathrm{kcal} / \mathrm{mol}$. This agrees to IP values and explains the higher value of $210.17 \mathrm{kcal} / \mathrm{mol}$ for the PI of derivative 4 of ascorbic acid, which does not have the enolic hydroxyls.

According to these results, the 3,4-dihydro-furan-2-one system (5) is the most important and essential group for the antioxidant effect observed in ascorbic acid [30-33]. Consequently, similar structures that can be more potent than ascorbic acid in free radicals scavenging were proposed through molecular modifications [24, 27] that included: i) the molecular simplification by removal of primary and secondary alcohol from the saturated chain, ii) the removal of carbonyl for the formation of the ether in simplified ring (6), iii) the addition of a second carbonyl in the $\delta$ position for the formation of the anhydride derivative (7), and the modification of the lactone group to obtain an aliphatic (8) and olefinic ketone (9). 
According to these proposals, the absence of the carbonyl group decreased the values of IP and $\mathrm{BDE}_{\mathrm{OH}}$ to 184.30 and $76.94 \mathrm{kcal} / \mathrm{mol}(6)$ and the presence of an extra carbonyl increased these values to 225.99 and $97.64 \mathrm{kcal} / \mathrm{mol}$ (7). These results are accompanied by the lower SET and HAT values of -9.20 and $-4.03 \mathrm{kcal} / \mathrm{mol}(6)$ and higher values of 32.48 and $16.67 \mathrm{kcal} / \mathrm{mol}$ (7), respectively. The presence of the keto-alkene group (9) showed the best values of IP and $\mathrm{BDE}_{\mathrm{OH}}(186.29$ and $77.48 \mathrm{kcal} / \mathrm{mol})$ when compared to the keto-alkane compound (8), whose values increased to 199.01 and $89.77 \mathrm{kcal} / \mathrm{mol}$. These results are also accompanied by the lower SET and HAT values of -7.21 and $-3.49 \mathrm{kcal} / \mathrm{mol}$ for keto-alkene (9) and higher SET and HAT values of 5.50 and $8.80 \mathrm{kcal} / \mathrm{mol}$ for keto-alkane (9).

Table 1 Theoretical parameters for ascorbic acid and related derivatives.

\begin{tabular}{ccccccccc}
\hline Compound & $\mathbf{I P}$ & $\mathbf{S E T}$ & $\mathbf{B D E}_{\mathbf{O H}}{ }^{\mathbf{a}}$ & $\mathbf{B D E}_{\mathbf{O H}}{ }^{\mathbf{b}}$ & $\mathbf{H A T}$ & SPLET $^{\mathbf{B D E}_{\mathbf{O H}}}{ }^{\mathbf{c}}$ & $\mathbf{S E A}^{\text {SEA }}$ \\
\hline $\mathbf{1}$ & 193.51 & 0 & 86.24 & 80.97 & 0 & 72.12 & 70.14 & -68.41 \\
$\mathbf{2}$ & 211.49 & 17.97 & - & 91.70 & 10.73 & 87.66 & - & - \\
$\mathbf{3}$ & 206.14 & 12.63 & - & 99.99 & 19.02 & 70.41 & - & - \\
$\mathbf{4}$ & 210.17 & 16.66 & - & - & - & - & - & - \\
$\mathbf{5}$ & 202.15 & 8.63 & 97.20 & 82.75 & 1.78 & 60.43 & 69.90 & -60.43 \\
$\mathbf{6}$ & 184.30 & -9.20 & 76.94 & 76.94 & -4.03 & 35.75 & 59.59 & -35.75 \\
$\mathbf{7}$ & 225.99 & 32.48 & 97.64 & 97.64 & 16.67 & 79.36 & 71.97 & -79.36 \\
$\mathbf{8}$ & 199.01 & 5.50 & 94.48 & 89.77 & 8.80 & 55.72 & 72.73 & -55.72 \\
$\mathbf{9}$ & 186.29 & -7.21 & 77.61 & 77.48 & -3.49 & 46.60 & 63.02 & -46.60 \\
\hline
\end{tabular}

$\mathrm{BDE}_{\mathrm{OH}}$ values: abstraction of hydrogen for a) $\beta$ position, b) $\alpha$ position, and c) quinone formation.

The same disposition was observed for the SPLET mechanism and for the quinone (MolQ) formation, revealing $\mathbf{6}$ and $\mathbf{9}$ derivatives have the best performance by the lowest values for these properties of 35.75 and $59.59 \mathrm{kcal} / \mathrm{mol}$ (6) and 46.60 and $63.02 \mathrm{kcal} / \mathrm{mol}$ (9), respectively. Finally, according to the single electron acceptance (SEA) values for the quinone derivatives, the presence of the cabonyl group is important for the best values [34]. The SEA values followed the order: dicarbonyl $7(-79.36 \mathrm{kcal} / \mathrm{mol})>$ carbonyl $5(-60.43 \mathrm{kcal} / \mathrm{mol})>$ ketoalkane $8(-55.72 \mathrm{kcal} / \mathrm{mol})>$ keto-alkene $9(-46.60 \mathrm{kcal} / \mathrm{mol})$ and ketone $6(-35.75 \mathrm{kcal} / \mathrm{mol})$, when compared to ascorbic acid $1(-68.41 \mathrm{kcal} / \mathrm{mol})$. Thus, the keto-alkene 9 can be a good strategy on design of potent antioxidant related to ascorbic acid.

\section{Conclusion}

According to our obtained theoretical results, the keto-alkene compound showed the best values when compared to ascorbic acid. However, it is surprising the superiority of the redox 
property of ascorbic acid in comparison to the derivatives proposed in this work. Except for SEA, all suggested molecules showed better values for the studied parameters. In this sense, it is possible that the best natural compounds that act as antioxidants have an average value for all properties, and ascorbic acid can be act by several antioxidant mechanisms.

\section{*Declarations}

Funding: Authors are grateful to $\mathrm{CNPq}$ for financial support.

Conflicts of interest/Competing interests: The authors declare that they have no conflict of interest.

\section{Ethics approval: NA}

Consent to participate: NA

Consent for publication: Yes.

Availability of data and material: NA

Code availability: Gaussian 09 software code G9S016832734579W-5269N

Authors' contributions: Conceptualization, Kelton L. B. Santos and Rosivaldo S. Borges; data extraction, Kelton L. B. Santos and Larysse V. Pacheco; structure-reactivity, Vitor A. N. Bragança; calculations, Kelton L. B. Santos; electronic properties, Sirlene S. B. Ota; editing, Christiane P. O. Aguiar; final version, Rosivaldo S. Borges.

\section{References}

[1] Sorice A, Guerriero E, Capone F, Colonna G, Castello G, Costantini S (2014) Mini Rev Med Chem 14(5):444-452

[2] Du J, Cullen JJ, Buettner GR (2012) Biochim Biophys Acta 1826(2):443-457

[3] Aditi A, Graham DY (2012) Dig Dis Sci 57(10):2504-2515

[4] Padayatty SJ, Katz A, Wang Y, Eck P, Kwon O, Lee J-H, Chen S, Corpe C, Dutta A, Dutta SK, Levine M (2013) J Am College Nut 22(1):18-35

[5] Berg RW (2015) Applied Spect Rev 50(3):193-239

[6] Higgins MR, Izadi A, Kaviani M (2020) Int J Environ Res Public Health 17(22):8452

[7] Baschieri A, Amorati R, Benelli T, Mazzocchetti L, D’Angelo E, Valgimigli L (2019) Antioxidants 8(2):30

[8] Bradshaw MP, Barril C, Clark AC, Prenzler PD, Scollary GR (2011) Crit Rev Food Sci Nut 51(6):479-498

[9] Gueguen S, Pirollet P, Leroy P, Guilland J-C, Arnaud J, Paille F, Siest G, Visvikis S, Hercberg S, Herbeth B (2003) J Am Coll Nut 22(4):303-310

[10] Rahal A, Kumar A, Singh V, Yadav B, Tiwari R, Chakraborty S, Dhama K (2014) Biomed Res Int 2014:761264

[11] Kaźmierczak-Barańska J, Boguszewska K, Adamus-Grabicka A, Karwowski BT (2020) Nutrients 12(5):1501

[12] Gale CR, Ashurst HE, Powers HJ, Martyn CN (2001) Am J Clin Nutr 74(3):402-408 
[13] Kim T-J, Byun J-S, Kwon HS, Kim D-Y (2018) Biochem Biophys Res Commun 497(1):347-353

[14] Shenoy N, Creagan E, Witzig T, Levine M (2018) Cancer Cell 34(5):700-706

[15] Moritz B, Schmitz AE, Rodrigues ALS, Dafre AL, Cunha MP (2020) J Nut Biochem 85:108459

[16] Nimse SB, Pal D (2015) RSC Adv 5:27986-28006

[17] Stewart JJP (2004) J Mol Model 10(2):155-164

[18] Theophilou AK (2018) J Chem Phys 149:074104

[19] Lee C, Yang W, Parr RG (1998) Phys Rev B 37:785-789

[20] Yu JK, Bannwarth C, Hohenstein EG, Martínez TJ (2020) J Chem Theory Comput 16(9):5499-5511

[21] Frisch MJ, Trucks GW, Schlegel HB, Scuseria GE, Robb MA, Cheeseman JR, Scalmani G, Barone V, Petersson GA, Nakatsuji H, Li X, Caricato M, Marenich A, Bloino J, Janesko BG, Gomperts R, Mennucci B, Hratchian HP, Ortiz JV, Izmaylov AF, Sonnenberg JL, WilliamsYoung D, Ding F, Lipparini F, Egidi F, Goings J, Peng B, Petrone A, Henderson T, Ranasinghe D, Zakrzewski VG, Gao J, Rega N, Zheng G, Liang W, Hada M, Ehara M, Toyota K, Fukuda R, Hasegawa J, Ishida M, Nakajima T, Honda Y, Kitao O, Nakai H, Vreven T, Throssell K, Montgomery-Jr JA, Peralta JE, Ogliaro F, Bearpark M, Heyd JJ, Brothers E, Kudin KN, Staroverov VN, Keith T, Kobayashi R, Normand J, Raghavachari K, Rendell A, Burant JC, Iyengar SS, Tomasi J, Cossi M, Millam JM, Klene M, Adamo C, Cammi R, Ochterski JW, Martin RL, Morokuma K, Farkas O, Foresman JB, Fox DJ, Gaussian 09, Revision A.02, (2016)

[22] Lobato CC, Ordoñez ME, Queiroz RL, Santos CBR, Borges RS (2020) Chem Data Collect 28:100464

[23] Messaadia L, Bekkar Y, Benamira M, Lahmar H (2020) Chem Phys Impact 1:100007

[24] Queiroz AN, Gomes BAQ, Moraes WM, Borges RS (2009) Eur J Med Chem 44(4):16441649

[25] Borges RS, Queiroz AN, Mendes APS, Araújo SC, França LCS, Franco ECS, Leal WG, da Silva ABF (2012) Int J Mol Sci 13(6):7594-7606

[26] Leopoldini M, Russo N, Toscano M (2011) Food Chem 125(2):288-306

[27] Borges RS, Castle SL (2015) Bioorg Med Chem Lett 25(21):4808-4811

[28] Diniz JEM, Borges RS, Alves CN (2004) J Mol Struct THEOCHEM 673(1-3):93-97

[29] Alves CN, Borges RS, da Silva ABF (2006) Int J Quantum Chem 106(13):2617-2623

[30] das Neves PAPFG, Lobato CC, Ferreira LR, Bragança VAN, Veiga AAS, Ordoñez ME, Barros VA, de Aguiar CPO, Borges RS (2020) J Mol Model 26:318

[31] Demianenko E, Ilchenko M, Grebenyuk A, Lobanov V, Tsendra O (2014) J Mol Model 20(3): 2128

[32] Bichara LC, Lanús HE, Nieto CG, Brandán AS (2010) J Phys Chem A 114(14):4997-5004

[33] Borges RS, Costa FM, Pereira TL, Araújo RL, Almeida ED, da Silva ABF (2018) J Braz Chem Soc 29(3):609-614 
[34] Borges RS, Carneiro AS, Barros TG, Barros CAL, Chaves Neto AMJ, da Silva ABF (2014) J Mol Model 20(12):2541 


\section{Supplementary Files}

This is a list of supplementary files associated with this preprint. Click to download.

- Graphicalabstract.doc 